\title{
REVIEW ON ADVANCED TECHNOLOGIES FOR ALUMINUM RECOVERY FROM CARTON PACKAGES WASTE USING PYROLYSIS
}

\section{REVISÃO SOBRE TECNOLOGIAS AVANÇADAS PARA A RECUPERAÇÃO DE ALUMÍNIO DE RESÍDUOS DE EMBALAGENS CARTONADAS USANDO PIRÓLISE}

\section{Diunay Zuliani Mantegazini ${ }^{1}$, Fernando Luiz Neves², Thiago Padovani Xavier ${ }^{3 *}, \&$ Marcelo Silveira Bacelos ${ }^{4}$}

\author{
${ }^{13}$ Centro Universitário Norte do Espírito Santo da Universidade Federal do Espírito Santo. \\ 2 Tetra Pak, Desenvolvimento Ambiental. \\ ${ }^{1}$ diunayzmantegazini@gmial.com² fernando.neves@tetrapak.com3* thiago.p.xavier@ufes.br \\ ${ }^{4}$ marcelo.bacelos@ufes.br
}

\section{ARTIGO INFO.}

\section{Recebido em: 02.03.2021}

Aprovado em: 25.03.2021

Disponibilizado em: 31.03.2021

\section{Palavras-chave:}

LDPE/Al; Leito Fluidizado; Leito de Jorro; Plasma;

Potencial Econômico.

\section{KEYWORDS:}

LDPE/Al; Fluidized Bed; Spouted Bed; Plasma; Economic Potential.

*Autor Correspondente: Xavier, T. P.

\section{RESUMO}

A pirólise é uma tecnologia verde que permite separar o alumínio do polietileno das embalagens Tetra Pak. Essa alternativa pode ser utilizada para reduzir o impacto ambiental decorrente da destinação inadequada desses resíduos modernos. Além disso, a reciclagem permite recuperar materiais de alto valor agregado. Para a recuperação de alumínio e óleos parafínicos de resíduos de embalagens cartonadas, este artigo de revisão visa destacar os avanços na ciência e na tecnologia para a recuperação de alumínio de embalagens cartonadas. Dentre os reatores analisados, os leitos de jorro e os leitos fluidizados podem ser apontados como novas oportunidades e grandes sucessos do setor nos próximos anos. Em relação ao potencial econômico, dois fatores apontam a pirólise de resíduos de embalagens cartonadas como uma técnica promissora: o valor agregado dos materiais reciclados e a economia de energia do processo. Com base na análise econômica, a pirólise tem um potencial econômico positivo de 190,5 US\$/por tonelada de produto. Quando comparada ao processo tradicional de produção de alumínio, a pirólise pode economizar 0,745 MWh por cada tonelada de embalagem cartonada recuperada. No que diz respeito à rentabilidade do processo, a pirólise por plasma tem uma relação de caixa acumulada de 3,27 milhões e uma taxa de retorno do investimento de $2,04 \%$, mostrando-se um investimento atraente.

\begin{abstract}
Pyrolysis is green technology allowing for the separation of polyethylene and aluminum composite from Tetra Pak. This alternative can be used to reduce the environmental impact arising from the unsuitable disposal of this modern waste. In addition, recycling enables the recovery high added value materials. For the recovery of aluminum and paraffinic oils from carton packaging waste, this review paper aims to highlight the advances in science and technology for aluminum recovery from carton packages. Among the reactors analyzed, spouted and fluidized beds can be pointed out as new opportunities and industry-leading successes over the upcoming years. Concerning economic potential, two factors show the pyrolysis of carton waste as a promising technique: the added value of recycled materials and process energy saving. Based on economic analysis, pyrolysis has a positive economic potential of 190.5 US\$/per ton of product. When compared with the traditional process to produce aluminum, pyrolysis can save $0.745 \mathrm{MWh}$ per ton of recovered carton package. Concerning the process profitability, plasma pyrolysis has a 3.27 Million cumulative cash ratio and a $2.04 \%$ rate of return on investment, showing itself as an attractive investment.
\end{abstract}



recovery from carton packages waste using pyrolysis. Brazilian Journal of Production Engineering, 7(1), 117-129.

\section{INTRODUCTION}

The carton package is composed of $70 \%$ cardboard, $25 \%$ low-density polyethylene (LDPE), and 5\% aluminum foil (Haydary et al., 2013). The world recycling of carton packages has been growing over the years reaching approximately 2,000 tons per year with a $26 \%$ recycling rate in 2018 (Tetra Pak, 2018). This alternative can be used to reduce the environmental impact arising from the unsuitable disposal of this modern waste in landfills - commonly used for underdeveloped countries. Besides, recycling enables the recovery of high added-value materials and reduces the amount of energy used for aluminum extraction from Bauxite ore.

Cardboard is recovered by a repulping process, generating LDPE and Aluminum layers as a by-product, which can be turned into pellet particles of LDPE/Al composite by thermal injection and extrusion. Polyolefin waste can be used to produce chemicals or fuels as reported by Lopez and co-workers and Butler and co-workers (Butler et al., 2011; Lopez et al., 2017), recovered by dissolving LDPE/Al composite using Xylene organic solvent with a $56 \%$ recovery rate as found by Cervantes-Reyes and co-workers (Cervantes-Reyes et al., 2015), or mixed with virgin polypropylene for tuning physical performance properties (Curtzwiler et al., 2019).

Pyrolysis is one of the technologies used in the recycling of carton packages that allows the separation of polyethylene from aluminum. It is currently reported as a sustainable, clean, and innovative technology. From the environmental point of view, by using pyrolysis it is possible to reduce $\mathrm{CO}_{2}$ emissions and the environmental impact with bauxite ore extraction. It is estimated that for each ton of primary aluminum produced from bauxite ore, 2 tons of $\mathrm{CO}_{2}$ will be generated and 5 tons of bauxite ores will be consumed (ABAL, 2010). The gases generated during the process can be used as fuel for heating the pyrolysis process itself or for generating electricity.

In 2005, the first plasma pyrolysis plant was built in Piracicaba-SP/Brazil for processing 32,000 tons/year carton packages. Electrical energy was used to obtain a plasma jet at $12,000^{\circ} \mathrm{C}$. The LDPE/Al composite (a mixture of Low-density polyethylene and aluminum) was converted to paraffinic oil, consequently, high purity aluminum was recovered. In 2011, Stora Enso, the second pyrolysis plant was started up in Barcelona/Spain to process 20,000 tons/year carton packages. The rotary drum operated at $500^{\circ} \mathrm{C}$. At Stora Enso, gas was used for power generation and is capable of supplying about $20 \%$ of the plant's energy needs.

Recently, with the thermal injection of LPDE and aluminum layers (i.e., carton packaging wastes) producing pellet particles (LPDE/Al composite) fluidization research could be developed. For a conical spouted bed composed of mixtures of sand and LDPE/Al composite $\left(\mathrm{d}_{\mathrm{p}}=2,58 \mathrm{~mm}\right)$, Melo and co-workers (Melo et al., 2016) have found a stable spouting regime was attained. The Euler-Euler disperse k- $\varepsilon$ models predicting axial particle concentrations did not show particle segregation in the bed. For fluidized beds comprise of sand and LPDE/Al mixtures $\left(\mathrm{d}_{\mathrm{p}}=550 \mu \mathrm{m}\right)$, Freitas and co-workers (Freitas et al., 2017) have reported a bubble fluidization regime was achieved. The predicted axial particle concentration by Euler-Euler laminar model showed a uniform axial particle concentration in the bed column. These results indicate a good solid mixing using sand and LPDE/Al mixtures in fluidized and spouted beds. 
Citação (APA): Mantegazini, D. Z., Neves, F. L., Xavier, T. P., \& Bacelos, M. S. (2021). Review on advanced technologies for aluminum recovery from carton packages waste using pyrolysis. Brazilian Journal of Production Engineering, 7(1), 117-129.

For the pyrolysis of post-consumer carton packages, a great variety of gas-solid contactors can be used as a reactor. To select the better reactors for processing of post-consumer carton packages detailed analyses of the process is needed, including 1) physical properties of raw materials and their classification based on Geldard`s (1973) diagram (Geldart, 1973); 2) size of the plant; 3) preparing system of fresh feeding as heat or size reduction and 4) capital investment available to build the reaction and integration energy systems. On the other hand, before plant designing, an engineer needs to deal with a complex synthesis problem, involving the sequence of process subsystems (i.e., reaction, separation, and energy integration) to achieve the required quality and amount of desired product.

Based on the literature review this research paper aims not only to highlight the advances in science and technology for aluminum recovery from carton packages but also to focus on the existing process allowing for the separation of aluminum in large-scale production. Moreover, efforts on technological routes for cardboard recovery from carton packages are pointed out; pyrolysis economic potential is analyzed and a process flow diagram for aluminum recovery is proposed including either fluidized or conical spouted beds as upcoming reactors for LDPE/Al composite pyrolysis reaction.

\section{CARTON PACKAGING RECOVERY ROUTES}

Because of the high carton market demand, these post-consumer packages are considered solid waste in potential, especially in countries where legislation laws are not rigorously put into practice. Therefore, to avoid great environmental impacts in large urban areas, studies on routes of either recycling or recovering post-consumer carton packages are needed.

For recycling post-consumer cartons, the separation of multilayers compounds presented in the packages is required. Figure 1 illustrates the key technologies applied for waste recovery from carton packaging. In Brazil, they can be recovered in various ways, such as injection/extrusion, pressing, pyrolysis/plasma excepting for incineration.

Figure 1. Main technologies applied for the recovery of carton packages.

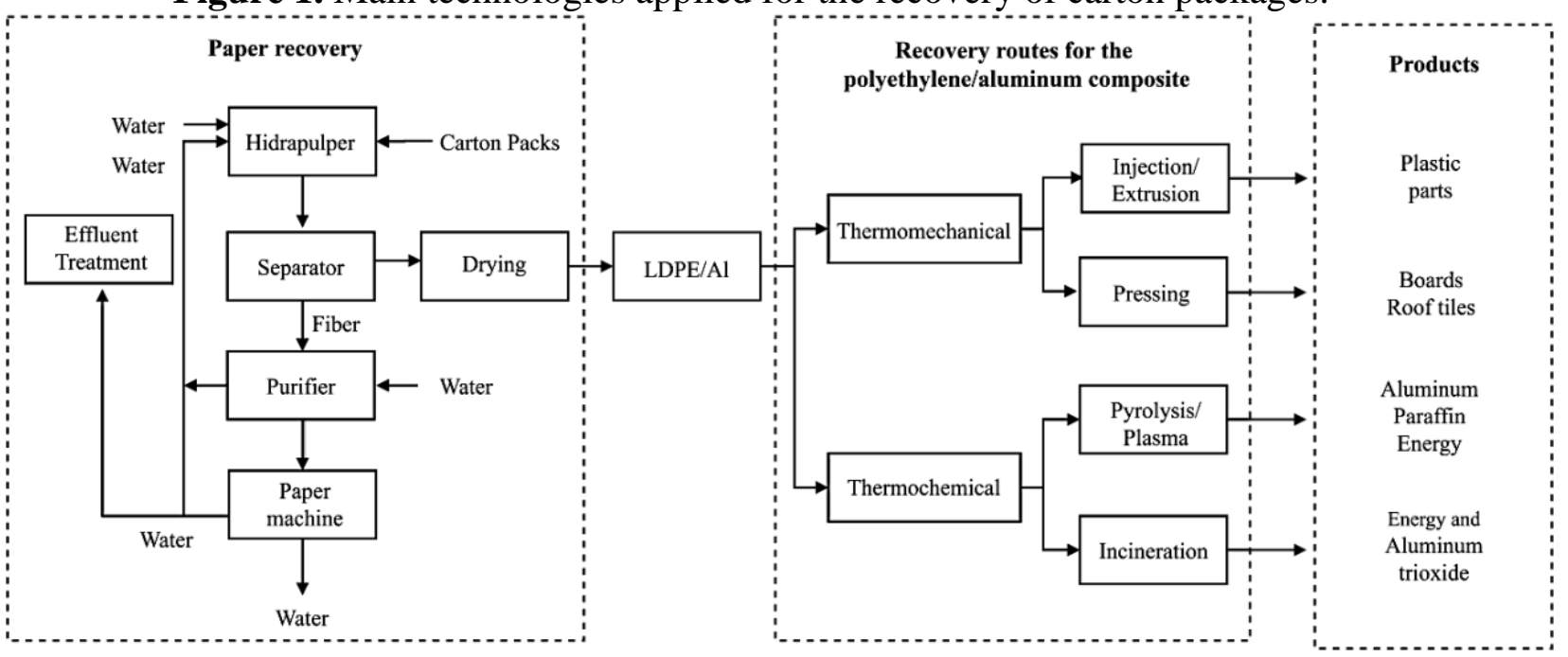

Source: Authors (2020).

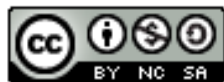


Citação (APA): Mantegazini, D. Z., Neves, F. L., Xavier, T. P., \& Bacelos, M. S. (2021). Review on advanced technologies for aluminum recovery from carton packages waste using pyrolysis. Brazilian Journal of Production Engineering, 7(1), 117-129.

The process of recovering carton packages begins with the recovery of paper through hydration and agitation of the fibers. The residue of this primary separation (polyethylene and aluminum mixture) can be recovered by thermomechanical or thermochemical processes.

The recovery of paper from carton packages consists of repulping the paper fibers from the polyethylene and aluminum layers by mechanical agitation with water (agitator angular velocity from 280 to $450 \mathrm{rpm}$ ) (Neves, 1999). Then, paper fibers are released from waste layers and maintained in water suspension, being withdrawn by pumping. The wastes i.e., aluminum and polyethylene layers, are pressed to withdraw the excess of water and dried to reduced moisture content using open-air drying (Neves, 1999).

To reduce operating costs part of the water used for the repulping stage is recycled. This makes it possible as the agitation of the carton material uses only water, without any chemical additives or heat (Neves, 1999). These results in a recycling water stream with the same temperature and pressure conditions as the makeup water stream added to the process.

The recovery of polyethylene and aluminum occurs by thermomechanical and thermochemical processes. In the extrusion, the polyethylene and aluminum layers are transformed into pellet-shaped LDPE/Al composite. These are used as raw materials to produce plastic components by injection and rotational molding or air blowing. By pressing, the LDPE/Al composite is transformed into boards or roof tiles, commonly used in civil construction. By pyrolysis of LDPE/Al composite, polyethylene and aluminum layers are separated. This innovative technology allows for obtaining paraffinic oil and high purity aluminum. By incineration, the combustion of waste enables the generation of steam and energy. In addition to water vapor, the combustion of the LDPE/Al composite produces carbon dioxide and solid aluminum trioxide, which can be used as either a flocculating agent in water treatment plants or a refractory agent in blast furnaces operations. This route is used by some European countries that have incinerators with strict environmental controls prepared for energy recovery.

\section{ECONOMIC POTENTIAL}

Two factors point to the pyrolysis of carton waste as a promising technique: the added-value of recycled materials and energy savings. Concerning value-adding, a mass balance along with a simple cost analysis between the outputs (products) and inputs (carton packages) can be performed to indicate the economic value generation of this process.

For the LDPE/Al composite pyrolysis processes the costs of raw materials and products are presented in Table 1.

Table 1. Costs of raw materials and products.

\begin{tabular}{ccc}
\hline Input & Description & Value (USD/ton) \\
\hline Raw material & Carton packages & 120.00 \\
& Recycled paper & 120.00 \\
Product & Aluminum & 2500.00 \\
& Paraffin & 500.00 \\
\hline
\end{tabular}

Source: Pedroso and Zwicker (2007). Adapted.

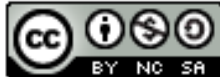



recovery from carton packages waste using pyrolysis. Brazilian Journal of Production Engineering, 7(1), 117-129.

Based on data presented by Pedroso and Zwicker (2007), Figure 2 shows the input and output structure of paper recycling and aluminum recovery processes by plasma pyrolysis. The paper recycling process has a recycling efficiency of $95 \%$ (Every $750 \mathrm{~kg}$ of paper fibers, is recovered a total of $712.5 \mathrm{~kg}$ of paper). In the aluminum recovery process, an efficiency of $100 \%$ is considered, including aluminum oxide due to passivation.

Based on an economic analysis of the input and output structure of the paper recycling and aluminum recovery process, it can be shown that it has a positive economic potential, aggregating $190.5 \mathrm{USD} / \mathrm{t}$ of product.

Figure 2. Economic analysis for the recycling of carton packages.

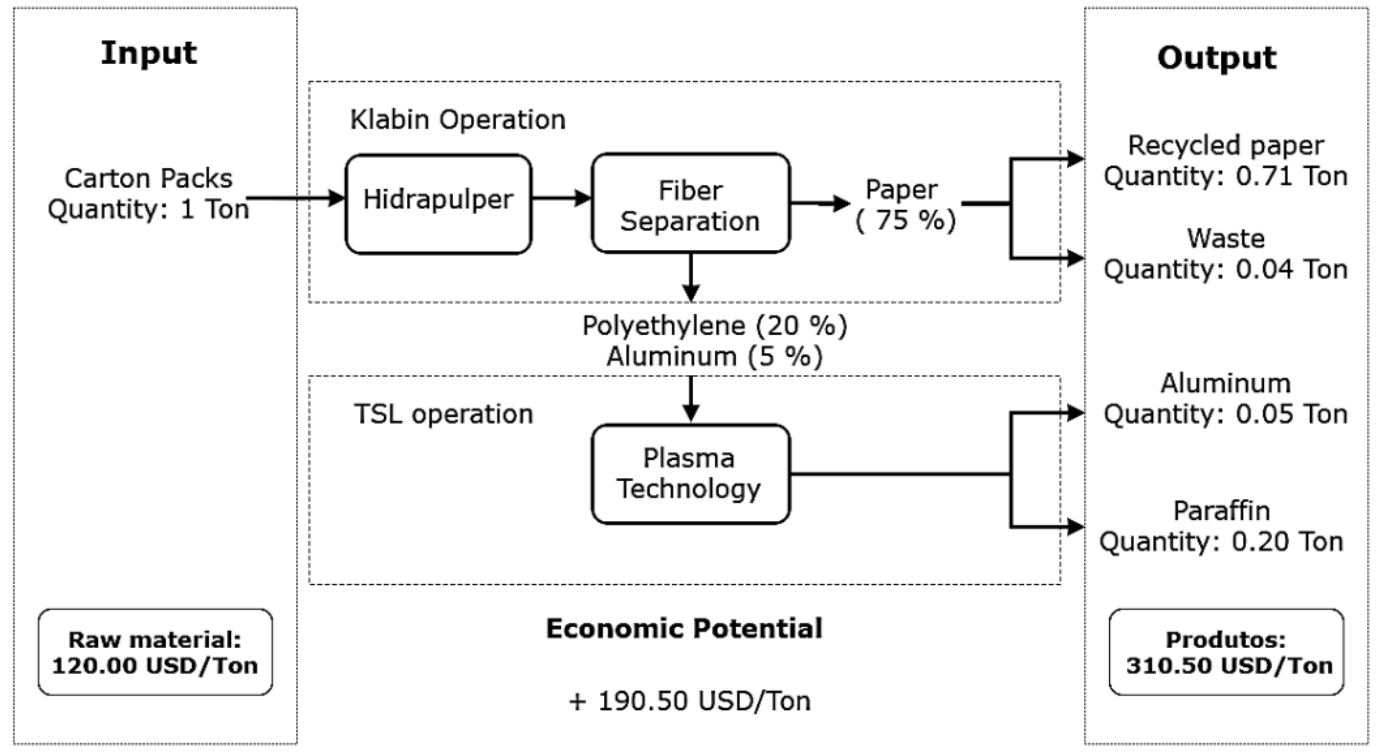

Source: Pedroso and Zwicker (2007). Adapted.

Figure 3 shows a flowchart with the following paper separation processes and pyrolysis reaction of the LDPE / $\mathrm{Al}$ composite. Through a mass balance, it could be noted that each 1 ton of carton package generates $712.5 \mathrm{~kg}$ paper and $50 \mathrm{~kg}$ aluminum (including aluminum oxide due to passivation).

Figure 3. Mass balance of the carton pack recovery process.

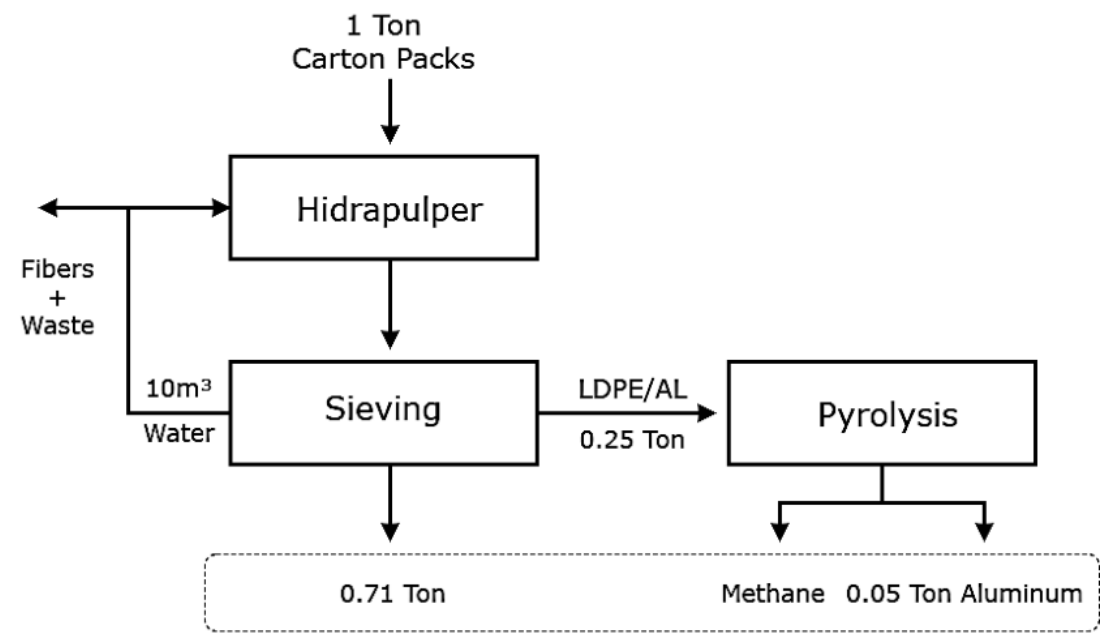

Source: Neves (1999). Adapted. 
Citação (APA): Mantegazini, D. Z., Neves, F. L., Xavier, T. P., \& Bacelos, M. S. (2021). Review on advanced technologies for aluminum recovery from carton packages waste using pyrolysis. Brazilian Journal of Production Engineering, 7(1), 117-129.

According to Associação Brasileira do Alumínio (ABAL, 2010) energy consumption for primary and recycled aluminum production is presented in Table 2.

Table 2. Energy consumption in aluminum production in 2010.

\begin{tabular}{ccc}
\hline & Primary Aluminum & Recycling * \\
\cline { 2 - 3 } Production (1000 ton) & 1536 & 488 \\
Energy consumption $(\mathrm{GWh})$ & 23982 & 342 \\
Specific energy consumption $(\mathrm{MWh} / \mathrm{t})$ & 15.6 & 0.7 \\
\hline
\end{tabular}

* concerning scrap recovery.

Source: ABAL (2010). Adapted.

For the pyrolysis process, it is assumed that the energy consumption for aluminum recovery is equal to that obtained by the recycling process. For each 1 ton of recovered carton packages, 0.05 tons of aluminum is obtained. To produce 0.05 tons of aluminum by the traditional process is spent $0.78 \mathrm{MWh}$, while for the same amount by pyrolysis only consumes 0.035 MWh. By analyzing the energy spent by both processes, it can be concluded the usage of pyrolysis can save $0.745 \mathrm{MWh}$ per ton of recovered carton package.

In Brazil, in 2011, according to CEMPRE (2019), the recycling rate of carton packages was 59 thousand tons/year. If all this carton packaging wastes demand were recovered by pyrolysis, the saved energy would be approximately $44 \mathrm{GWh}$, resulting in the amount of recycled aluminum equals to 2,950 tons/year. Comparing this annual amount of aluminum from the pyrolysis of the carton with that primary aluminum, it can be stated that pyrolysis can reach twice the Brazilian annual amount of primary aluminum. This is not considering the aluminum passivation.

From an environmental point of view, the production of 1 ton of aluminum consumes approximately 5 tons of Bauxite ore (ABAL, 2010). On the other hand, pyrolysis of 59 thousand tons of carton packages saves 14,750 tons of bauxite, reducing the environmental impact with the extraction of bauxite ore.

Concerning the $\mathrm{CO}_{2}$ emissions, it is estimated that for each 1 ton of primary aluminum from Bauxite ore 2 tons of $\mathrm{CO}_{2}$ are generated. Currently, world aluminum production accounts for $1 \%$ of anthropogenic greenhouse gas emissions (ABAL, 2010).

In 2011, Store Enso Company in Barcelona, Spain started up a pyrolysis plant for processing carton packaging waste. The plant could process 20,000 tons of carton packages annually. Brazil was a pioneer in developing an aluminum recovery process from carton packages. In 2005, a pyrolysis plant located in Piracicaba-SP/Brazil was inaugurated using a partnership between the companies Klabin, Tetra Pak, Alcoa, and TSL Ambiental. The new factory used plasma technology, which allowed for the separation of aluminum and polyethylene. The new plasma used to have the capacity to process 8,000 tons/year of polyethylene and aluminum. This is equivalent to 32,000 tons of recycled carton packages in total.

For the pyrolysis plant located in Piracicaba-SP/Brazil, it is calculated the Revenue (R), fixed capital investment (FCI), cost of manufacture $\left(\mathrm{COM}_{\mathrm{d}}\right)$, annual depreciation $(\mathrm{d})$, and tax rate (t), which are presented in Table 3. These are based on data estimated by Pedro and Zwiker (2007).

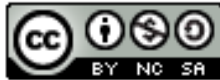



recovery from carton packages waste using pyrolysis. Brazilian Journal of Production Engineering, 7(1), 117-129.

For estimating after-tax cash flow and profits in terms of revenue, cost of manufacture, depreciation, and tax rate the following equations are used (Turton, et al., 2012):

$$
\text { After }- \text { Tax cash flow }=\left(R-\mathrm{COM}_{d}-\mathrm{d}\right) .(1-\mathrm{t})+\mathrm{d}
$$

Where: $\mathrm{R}$ is the revenue (USD/y); $\mathrm{COM}_{\mathrm{d}}$ is the cost of manufacture (USD/y) excluding depreciation; $t$ is the investment tax rate required (it is used 35\%) and $\mathrm{d}$ is the MACRS depreciation using a is 5-year recovery period (USD/y).

For nondiscounted profitability, Table 3 shows the annual after-tax cash flow and cumulative cash flow for the plasma pyrolysis process.

Table 3. No discounted After-Tax Cash Flows (All Numbers in USD 106).

\begin{tabular}{ccccccccc}
\hline $\begin{array}{c}\text { End } \\
\text { of } \\
\text { Year }\end{array}$ & Investment & D k & FCI L-D k & R & COMd & $\begin{array}{c}\text { (R-COMd-Dk)*(1- } \\
\text { t)+Dk }\end{array}$ & $\begin{array}{c}\text { Cash } \\
\text { Flow }\end{array}$ & $\begin{array}{c}\text { Cumulative } \\
\text { cash flow }\end{array}$ \\
\hline 0 & 0,30 & --- & 5,00 & --- & --- & --- & 0,30 & $-0,30$ \\
1 & 3,00 & --- & 5,00 & --- & --- & --- & 3,00 & $-3,30$ \\
2 & 3,70 & --- & 5,00 & --- & --- & -- & 3,70 & $-7,00$ \\
3 & --- & 0,88 & 4,10 & 9,80 & 8,00 & 1,41 & 1,41 & $-5,50$ \\
4 & --- & 1,44 & 2,68 & 9,80 & 8,00 & 1,67 & 1,67 & $-3,90$ \\
5 & --- & 0,94 & 1,74 & 9,80 & 8,00 & 1,44 & 1,44 & $-2,40$ \\
6 & --- & 0,61 & 1,13 & 9,80 & 8,00 & 1,29 & 1,29 & $-1,10$ \\
7 & --- & 0,40 & 0,74 & 9,80 & 8,00 & 1,20 & 1,20 & 0,10 \\
8 & --- & 0,26 & 0,48 & 9,80 & 8,00 & 1,14 & 1,14 & 1,20 \\
9 & --- & 0,00 & 0,00 & 9,80 & 8,00 & 1,02 & 1,02 & 2,20 \\
10 & --- & 0,00 & 0,00 & 9,80 & 8,00 & 1,02 & 1,02 & 3,20 \\
11 & --- & 0,00 & 0,00 & 9,80 & 8,00 & 1,02 & 1,02 & 4,30 \\
12 & 2,00 & 0,00 & 0,00 & 9,80 & 8,00 & 1,02 & 2,97 & 7,30 \\
\hline
\end{tabular}

Source: Authors (2020).

According to Turton and co-authors (Turton, et al., 2008), for no discounted profitability, payback period (PBP), cumulative cash ratio (CCR), rate of return on investment (ROROI) are used as profitability criteria. Then, for the plasma pyrolysis process, Figure 4 shows the cumulative cash flow diagram using non-discounted profitability. For 10 years, the process has a 3.27 Million CCR and 2.04\% ROROI. 
Figure 4. Cumulative cash flow diagram for nondiscounted after-tax cash flows.

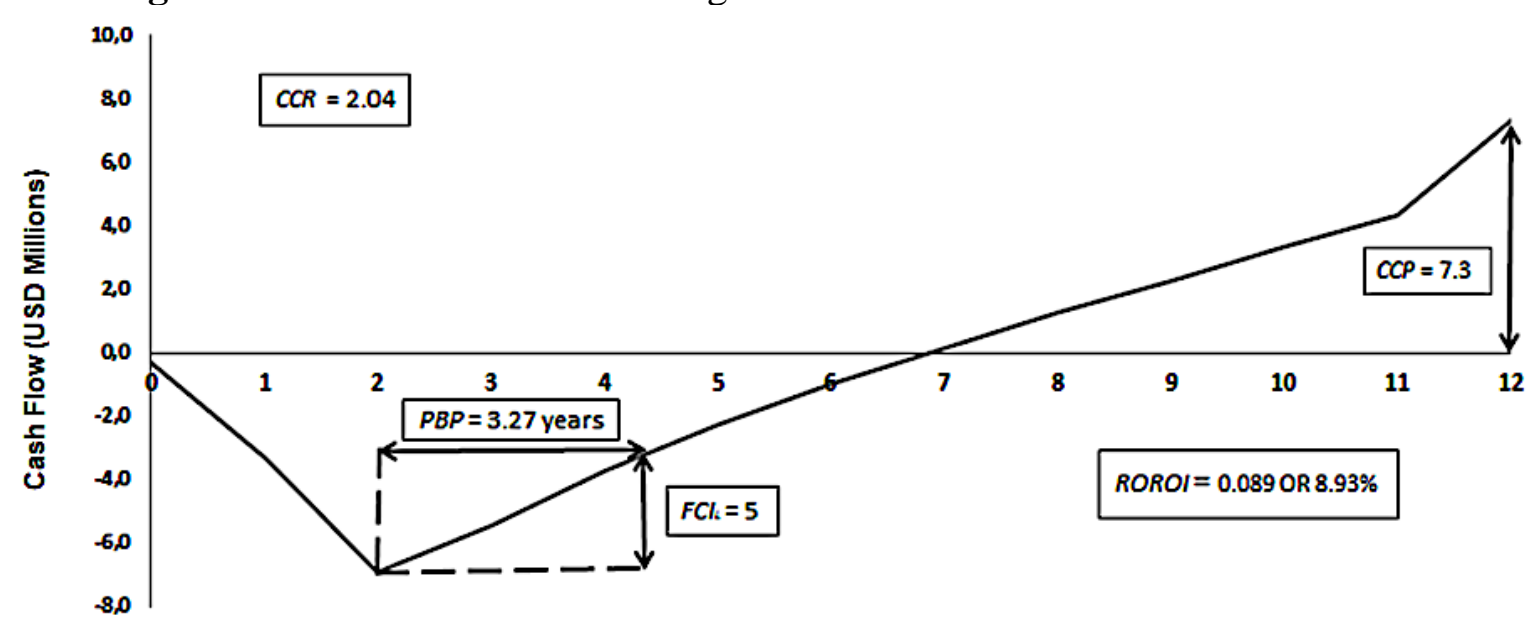

Time After Project Start

Source: Authors (2020).

\section{FLUID DYNAMIC PERFORMANCE OF UNCONVENTIONAL REACTORS FOR PROCESSING OF CARTON PACKAGING WASTE}

The gain of aluminum and polyethylene raw material as a composite particle using injection and extrusion allows it for the application of spouting and fluidized beds, which are considered innovative alternatives to pyrolysis due to their good gas-particle contact dealing with binary particle mixtures (sand and composite). Also, this feature has been evidenced by the success of these contact systems in a wide variety of processes such as drying, coating, granulating and mechanical extraction, among other applications.

For a given gas velocity injected into the bed, based on the fluidization regime map scheme in Figure 6 it can be noted that the fluidized bed operates satisfactorily using particles of group A (20 and $100 \mu \mathrm{m}$ ), B (40 to $500 \mu \mathrm{m}$ ), and C (less than $20 \mu \mathrm{m}$ ) and spouted bed using mainly group D particles (larger than $1 \mathrm{~mm}$ ).

In comparison between fluidized and spouted beds, it is observed that the spouted bed achieves fast fluidized bed velocity and pneumatic conveying. This results in vigorous solids movement and good particle mixing which contributes to pyrolysis reaction as a faster thermal solid decomposition and higher gas production can be achieved. Besides, due to the low segregation rate achieved by a spouted bed composed of the binary mixture as stated by (Olazar et al., 1993), (San Jose et al., 1994), (Bacelos \& Freire, 2006) and (Barcelos et al., 2020) such beds become a promising gas-solid contactor. 
Figure 5. Representative scheme based on the fluidization regime diagram of Grace and Olazar concerning the velocity modulus $\left(\mathrm{u}^{*}\right)$ and the particle size dimension $\left(\mathrm{d}_{\mathrm{p}} *\right)$.

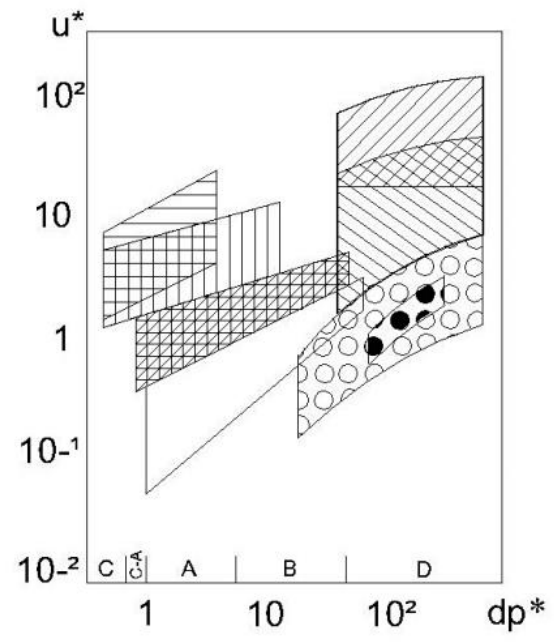

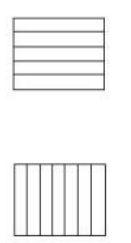

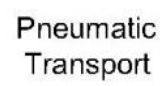

\section{Fast}

Fluidized Bed

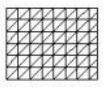

Turbulent

Fluidized Bed

Conventional Fluidized Bed

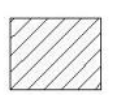

Conical Jet Spouted bed

Conical Spouted Bed

Spouted Bed

Mobile Bed

Source: Authors (2020). Adapted.

Based on these characteristics presented by the spouted and fluidized beds, studies on the application of these beds in the aluminum recovery of carton packages have been performed and reported in the literature.

Melo and co-workers (Melo et al., 2016) investigated the flow of LDPE/Al composite and sand particle mixtures ( $\mathrm{ds}=2.58 \mathrm{~mm}$; group $\mathrm{D}$ Geldart) in a conical spouted bed. The Gidaspow drag and disperse k- $\varepsilon$ model represented the flow characteristics of the conical spout bed composed of LDPE / $\mathrm{Al}$ and sand mixtures (from 15 to 85 w.t \%).

Alvarenga and co-workers (2016) have studied the devolatilization steps and kinetic models for estimating the activation energy of the pyrolysis reaction of waste cartons such as paper board and polyethylene. As an initial approach, this can be used to simulated pyrolysis of polyethylene in conical spouted bed reactors. Whereas, according to (Alvarenga et al., 2016), the thermal degradation of melted polyethylene presents a devolatilization step. Then, in the reactor, it is converted into vapor paraffinic oils which can be collected in the column top.

Freitas and co-workers (2017) analyzed fluid dynamics in fluidized beds composed of LDPE/Al particle mixtures (in the range of 600 to $500 \mu \mathrm{m}$, i.e., belonging to Geldart group B). At operating conditions close to the minimum fluidization dense particles concentrate at the bed bottom, while light particles on the bed top. When air velocities higher than that of minimum fluidization are used, this reduces segregation in such fluidized beds as the gravity on particles is unbalanced by drag force.

Żukowski and Berkowicz (Żukowski \& Berkowicz, 2019) proposed a new type of fluidized bed for the combustion of polyolefin (low-density solid fuel). Fluidized bed composed of cenospheres (with particle density lower than $1 \mathrm{~g} / \mathrm{cm}^{3}$ ) and polymeric particle mixtures were used. The process reached a $97-99 \%$ yield of polyolefin conversion at $800{ }^{\circ} \mathrm{C}$. Compared with sand, cenospheres particles allow for the elimination of diffusion flames and soot formation, 
Citação (APA): Mantegazini, D. Z., Neves, F. L., Xavier, T. P., \& Bacelos, M. S. (2021). Review on advanced technologies for aluminum recovery from carton packages waste using pyrolysis. Brazilian Journal of Production Engineering, 7(1), 117-129.

reduction of nitrogen oxides emission and power consumption to maintain fluidization regime.

\section{PROCESS DIAGRAMS}

The starting point for the flowchart generation of a process is called the embryo flowchart, considering only material operations. Figure 6 shows an embryo flowchart for the pyrolysis process of LDPE/Al composite pellets, in the form of a block diagram.

Figure 6. Embryo flowchart for the recovery of carton packages.

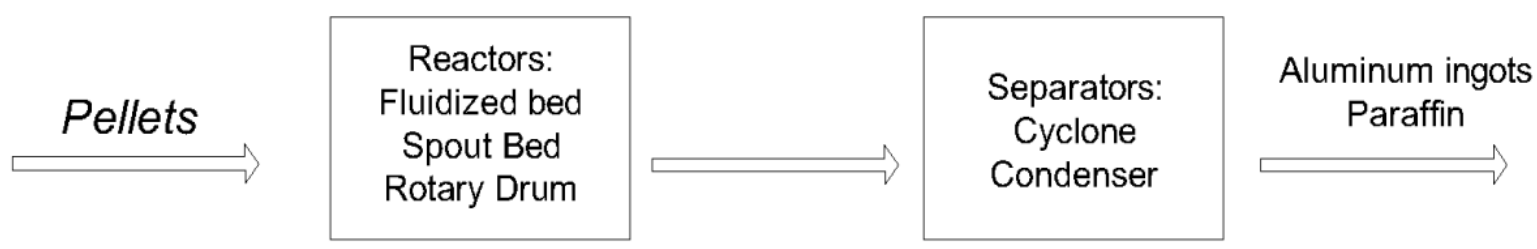

Source: Authors (2020).

The embryo flowchart consists only of reaction subsystems, developed based on the three main types of reactors (fluidized bed, spouted bed, and rotating drum) and separation subsystems consisting of cyclones and condensers, used respectively, to separate possible suspended solids in the gas stream and promote condensation of the products.

Figure 7 presents a general scheme of the carton packaging recovery process in the form of a block diagram, starting from the reaction, separation, and energy integration subsystems considered in the state tree.

Figure 7. Proposed block diagram for the recycling of carton packages.

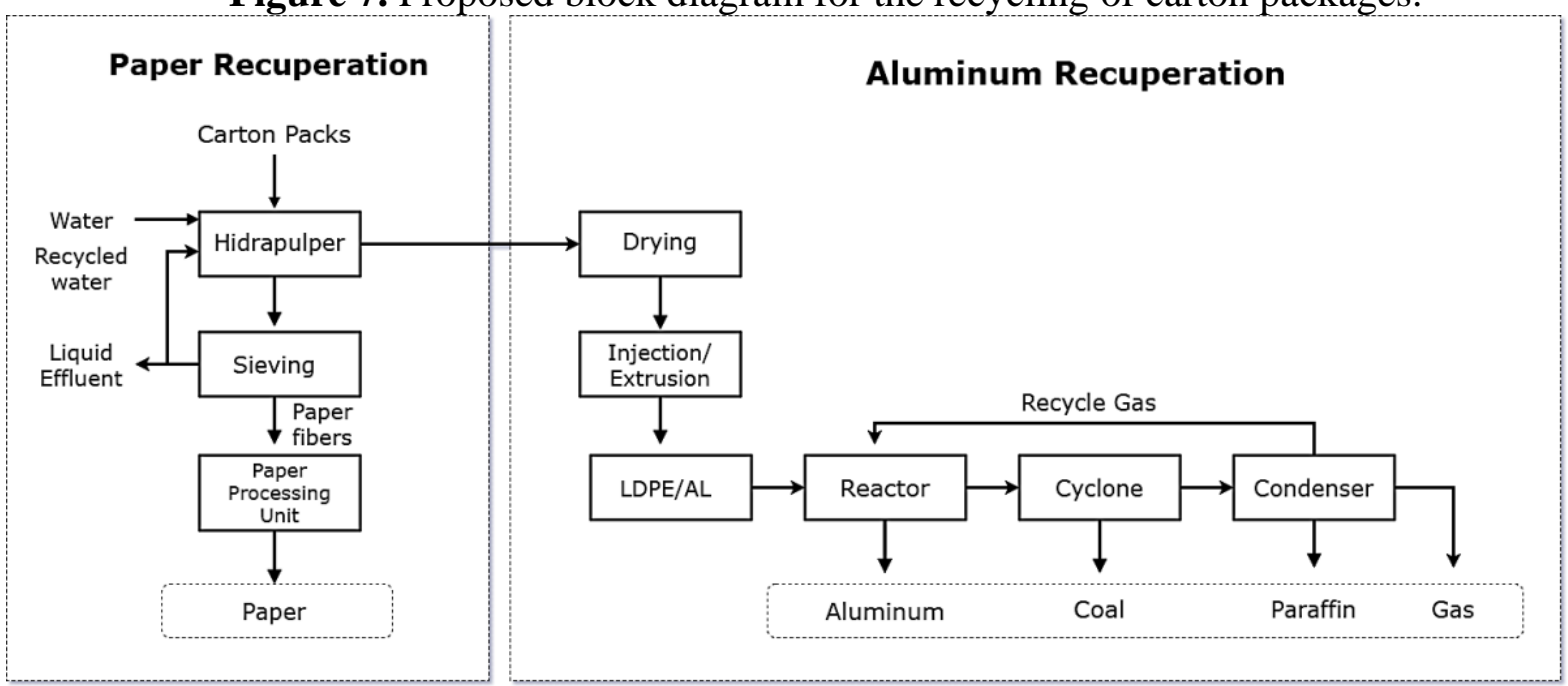

Source: Authors (2020).

Based on the diagram proposed by Geldart (1973), LDPE/Al particles are in the range of operating conditions of the fluidized bed, jet-spouted bed, and spouted bed reactors with a conical column.

For large scale-production beds composed of LDPE/Al particles need to operate at high gas velocities, resulting in vigorous solids movement, good particle mixing, fast thermal

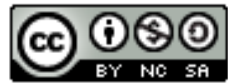


Citação (APA): Mantegazini, D. Z., Neves, F. L., Xavier, T. P., \& Bacelos, M. S. (2021). Review on advanced technologies for aluminum recovery from carton packages waste using pyrolysis. Brazilian Journal of Production Engineering, 7(1), 117-129.

decomposition, and high production rates. Therefore, the use of fluidized and spouted bed reactors is indicated as previously justified by the fluidization regime diagram.

To initiate the pyrolysis, the reactor is fed with LDPE/Al composite as showed in Figure 11. In the reactor, LDPE/Al composite particles absorb heat by convection due to the nitrogen flow and conduction due to the contact between sand and LDPE/Al composite. According to Artetxe and co-authors (Artetxe et al., 2010), polyethylene devolatilization can occur in the temperature range of $660,3{ }^{\circ} \mathrm{C}$ and aluminum needs to reach a higher temperature for melting (i.e., aluminum, melting point at $101.325 \mathrm{~Pa}$ pressure). Then, in the reactor, polyethylene is converted to paraffinic oils and removed at the reactor, while melting Aluminum can be collected at the reactor bottom.

The outlet reactor stream is sent to the cyclones to separate the coal particles present in the gas phase. The gaseous stream with coal particles enters tangentially at high speed into the cyclone forming a radial flow. By the action, centrifugal field particles are thrown against the wall and follow the descendent helical path due to the gravity force on particles. Then, a cleaner gas stream cooled at the temperature below the bubble point goes to phase separators where condensed gas is removed from no condensed ones. The bottom stream from the phase separator is cooled using a heat exchanger. As products paraffinic oil and gas are obtained.

Figure 8. Process flow diagram for aluminum recovery from LDPE/Al composite.

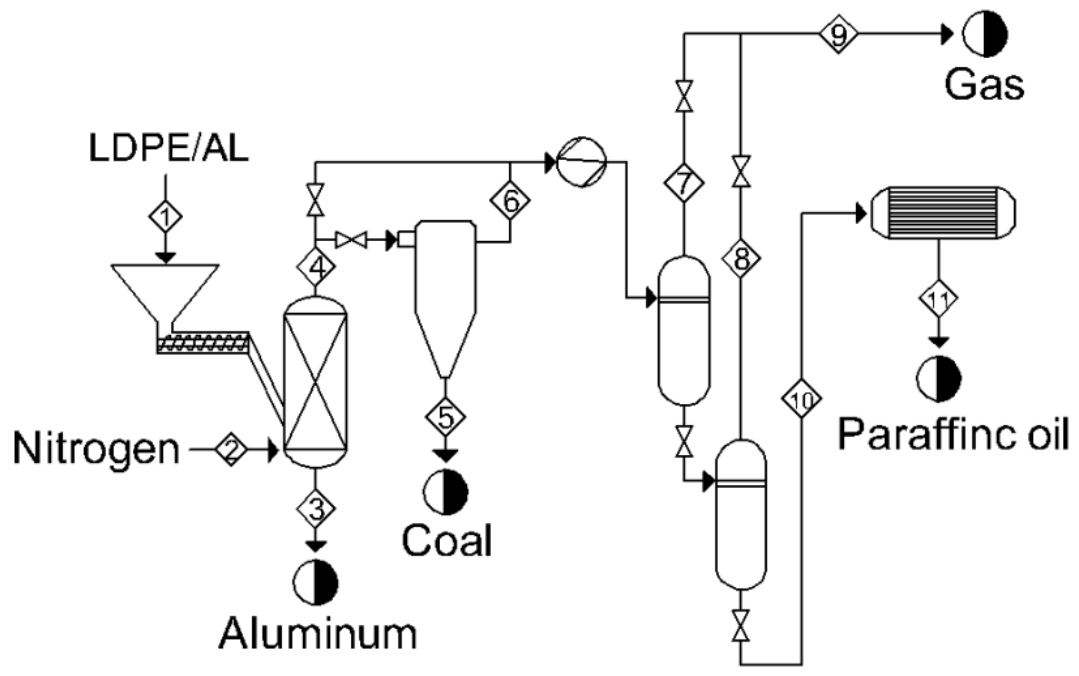

Source: Authors (2020).

The gases produced in pyrolysis can be used either for heating the pyrolysis process itself or electric power generation.

\section{OPPORTUNITIES FOR ALUMINUM RECOVERY FROM CARTON PACKAGES}

The aluminum recovery from carton packages has been presented a growing market demand over the years due to its high purity. Also, environmental and economic factors contribute to the accomplishment of the pyrolysis of LDPE/Al composite.

The environmental contribution is an important factor, as aluminum recovery contributes to the reduction of the environmental impact of bauxite ore extraction - each 1 ton of aluminum 
Citação (APA): Mantegazini, D. Z., Neves, F. L., Xavier, T. P., \& Bacelos, M. S. (2021). Review on advanced technologies for aluminum recovery from carton packages waste using pyrolysis. Brazilian Journal of Production Engineering, 7(1), 117-129.

requires approximately 5 tons bauxite ore. When compared with the traditional process, the amount of saved energy to obtain aluminum from pyrolysis is $0.745 \mathrm{MWh}$ per ton carton package.

To the process profitability in 10 years, plasma pyrolysis has a 3.27 Million cumulative cash ratio and $2.04 \%$ rate of return on investment, showing itself an attractive investment.

For future applications, conical spouted beds and fluidized beds can be used for pyrolysis of LDPE/Al composite as they can promote high heat and mass transfer rates in bed and operate with binary bed mixtures with low particle segregation.

\section{ACKNOWLEDGEMENTS}

The authors are grateful to the FAPES, CNPq and CAPES (Coordenação de Aperfeiçoamento de Pessoal de Nível Superior - Brasil - Finance Code 001), for their support.

\section{REFERENCES}

ABAL, (2010). Associação Brasileira do Alumínio - ABAL.

Alvarenga, L. M., Xavier, T. P., Barrozo, M. A. S., Bacelos, M. S., \& Lira, T. S. (2016). Determination of activation energy of pyrolysis of carton packaging wastes and its pure components using thermogravimetry. Waste management, 53, 68-75. https://doi.org/10.1016/j.wasman.2016.04.015.

Artetxe, M., Lopez, G., Amutio, M., Elordi, G., Olazar, M., \& Bilbao, J. (2010). Operating conditions for the pyrolysis of poly-(ethylene terephthalate) in a conical spouted-bed reactor. Industrial \& engineering chemistry research, 49(5), 2064-2069. https://doi.org/10.1021/ie900557c.

Bacelos, M. S., \& Freire, J. T. (2006). Stability of spouting regimes in conical spouted beds with inert particle mixtures. Industrial \& engineering chemistry research, 45(2), 808-817. https://doi.org/10.1021/ie050633s.

Barcelos, K. M., Almeida, P. S., Araujo, M. S., Xavier, T. P., Santos, K. G., Bacelos, M. S., \& Lira, T. S. (2020). Particle segregation in spouted bed pyrolysis reactor: Sand-coconut shell and sand-cocoa shell mixtures. Biomass and Bioenergy, 138, 105592. https://doi.org/10.1016/j.biombioe.2020.105592.

Butler, E., Devlin, G., \& McDonnell, K. (2011). Waste polyolefins to liquid fuels via pyrolysis: review of commercial state-of-the-art and recent laboratory research. Waste and biomass valorization, 2(3), 227-255.

CEMPRE, (2019). Embalagens Longa Vida, CEMPRE - Compromisso empresarial para a reciclagem.

Cervantes-Reyes, A., Núñez-Pineda, A., Barrera-Díaz, C., Varela-Guerrero, V., MartínezBarrera, G., \& Cuevas-Yañez, E. (2015). Solvent effect in the polyethylene recovery from multilayer postconsumer aseptic packaging. Waste Management, 38, 61-64. https://doi.org/10.1016/j.wasman.2015.01.034.

Curtzwiler, G. W., Schweitzer, M., Li, Y., Jiang, S., \& Vorst, K. L. (2019). Mixed postconsumer recycled polyolefins as a property tuning material for virgin polypropylene. Journal of Cleaner Production, 239, 117978. https://doi.org/10.1016/j.jclepro.2019.117978. 
Citação (APA): Mantegazini, D. Z., Neves, F. L., Xavier, T. P., \& Bacelos, M. S. (2021). Review on advanced technologies for aluminum recovery from carton packages waste using pyrolysis. Brazilian Journal of Production Engineering, 7(1), $117-129$.

Freitas, T. M., Arrieche, L. S., Ribeiro, D. C., Gidaspow, D., \& Bacelos, M. S. (2017). CFD analysis of fluidized beds using wastes from post-consumer carton packaging. Chemical Engineering and Processing: Process Intensification, 111, 89-100. https://doi.org/10.1016/j.cep.2016.12.002.

Geldart, D. (1973). Types of gas fluidization. Powder technology, 7(5), 285-292.

Haydary, J., Susa, D., \& Dudáš, J. (2013). Pyrolysis of aseptic packages (Tetra Pak) in a laboratory screw type reactor and secondary thermal/catalytic tar decomposition. Waste Management, 33(5), 1136-1141. https://doi.org/10.1016/j.wasman.2013.01.031.

Lopez, G., Artetxe, M., Amutio, M., Bilbao, J., \& Olazar, M. (2017). Thermochemical routes for the valorization of waste polyolefinic plastics to produce fuels and chemicals. A review. Renewable and Sustainable Energy Reviews, 73, 346-368.

Melo, J. L. Z., Bacelos, M. S., Pereira, F. A. R., Lira, T. S., \& Gidaspow, D. C. F. D. (2016). CFD modeling of conical spouted beds for processing LDPE/Al composite. Chemical Engineering and Processing: Process Intensification, 108, 93-108. https://doi.org/10.1016/j.cep.2016.07.011.

Neves, F. L. (1999). Reciclagem de embalagens cartonadas Tetra Pak. O Papel, 53(2), 38-45.

Olazar, M., San Jose, M. J., Penas, F. J., Aguayo, A. T., \& Bilbao, J. (1993). Stability and hydrodynamics of conical spouted beds with binary mixtures. Industrial \& engineering chemistry research, 32(11), 2826-2834. https://doi.org/10.1021/ie00023a053.

Pedroso, M. C., \& Zwicker, R. (2007). Sustentabilidade na cadeia reversa de suprimentos: um estudo de caso do Projeto Plasma. Revista de Administração-RAUSP, 42(4), 414-430.

San Jose, M. J., Olazar, M., Penas, F. J., \& Bilbao, J. (1994). Segregation in conical spouted beds with binary and ternary mixtures of equidensity spherical particles. Industrial \& engineering chemistry research, 33(7), 1838-1844. https://doi.org/10.1021/ie00031a025.

Tetra Pak, (2018). Post-consumer recycling of used carton packages.

Turton, R., Bailie, R. C., Whiting, W. B., \& Shaeiwitz, J. A. (2008). Analysis, synthesis and design of chemical processes. Pearson Education.

Żukowski, W., \& Berkowicz, G. (2019). The combustion of polyolefins in inert and catalytic fluidised beds. Journal of Cleaner Production, 236, 117663. https://doi.org/10.1016/j.jclepro.2019.117663. 